\title{
Experience in Use of 3D Printing in Engineering Education at University of Stavanger
}

\author{
Hirpa G. Lemu and Ove Mikkelsen \\ Faculty of Science and Technology, University of Stavanger
}

\begin{abstract}
This article is based on a project run in 2018 and 2019 entitled "Educating Mechanical Engineering using 3D Printing - Under3DP". The project was funded by Faculty of Science and Technology, University of Stavanger (UiS). The project is motivated by the current developments of the 3D printing technology in diverse disciplines whose initial inception was for rapid prototyping that can transform 3D models in computers to physical objects that the designer and/or the customer can touch, feel and better comprehend. Being one of the enablers of the digital transformations in manufacturing, the 3D printing technology is the fastest growing technologies and it is bringing more and more significant impacts to the manufacturing sector, healthcare, daily life, and the global economy. The pedagogical benefit of the project was evaluated using questionnaire based survey after the students of a course in Product Development and 3D Modelling have executed a mandatory group exercise to make 3D models of 3D printed samples and 3D print some of their 3D model ideas. According to the assessment results, more than $80 \%$ of the students who participated in the assessment responded that use of 3D fabricated parts in product design tasks have contributed to better understanding of the task and 3D printing has supported the learning process.
\end{abstract}

Keywords: 3D printing, hands-on learning, product design, Rapid prototyping, STEM education

\section{INTRODUCTION}

The technology that is, nowadays, referred to as $3 \mathrm{D}$ printing or additive manufacturing initially emerged 3 decades ago as a rapid prototyping tool. The initial inception of rapid prototyping was intended to better visualize and understand design concepts. It enables converting a computer model into a physical model that the designer and/or the customer can touch, feel and better comprehend. Furthermore, the technology has served as a motivation tool for generating innovative ideas and to cultivate creativity. The technology is fundamentally changing the way materials are processed and products are produced. Because of its suitability for processing complex geometries and its provision of design freedom, the technology is now being used beyond rapid prototyping $[1,2]$ including in manufacturing of functional parts diverse industrial sectors including the aerospace, automobile, energy and the medical sectors. The technology is also considered as one of the enablers of digital transformation in the manufacturing sector [3 - 5]. Being one of the fastest growing industries, 3D printing is thus bringing more and more significant impacts to the manufacturing sector, healthcare, daily life, and the global economy.

The education sector is no exception for this transformation supported by $3 \mathrm{D}$ printing technology. On one hand, significant interest is observed in integrating the science and technology of 3D printing in existing engineering curriculum [6] so that the graduates obtain necessary competence in the field to enable them to adapt to the digital transformation [7]. On the other hand, many universities and high schools [8], particularly in the core education areas such as science, technology, engineering and mathematics education (commonly referred to as STEM education) are bringing this technology in their classrooms [9] and equipping their laboratories with diverse variants of this technology. Many studies [10 - 11] indicate that 3D printing in education promotes active student involvement in the teachinglearning process and better communication.

Education of mechanical product design, which is the creation of machines and products, requires that students can think in three dimensions and visualize their ideas. Thus, wider utilization of 3D printing technology in education of product development, 3D modelling and mechanical design will enhance the learning process and increase innovative elements of our education. Furthermore, students can actively involve in the learning process, better visualize and get hands-on learning opportunities [12]. 
This article presents results of a project conducted at Faculty of Science and Technology of the University of Stavanger (UiS) to apply 3D printing technology as a tool of mechanical product design. By using 3D printing technology, the project team will study the benefits of the technology in improving the quality of our teaching and learning process and at the same time stimulate students for STEM education, i.e. attract better recruitment to mechanical engineering discipline.

\section{METHODOLOGY}

The project was implemented by equipping the 3D Printing laboratory of the Department of Mechanical and Structural Engineering and Materials Science (UiS) with small and low-cost 3D printers on which students can print their design concepts. In addition, models of difficult-to-grasp objects were printed for use in class as examples and demonstrations of mechanical parts and systems in product design related courses. To further contribute in stimulating hands-on and innovative learning process, three small 3D printer of different technologies, namely (1) Formlab Form 2 (Stereolitography technology), (2) Ultimaker S5 (Thermoplastic polymer extrusion technology) and Markforged Mark Two (Composite material printer) were purchased and made accessible for students. Furthermore, demonstrations of the $3 \mathrm{D}$ printers were organized for invited high school students in the region and during the open days at the university.

To evaluate the impact of the project in the course "Product Development and 3D Modelling" (MSK220), a mandatory 3D modelling task was arranged where student groups of up to three members were provided with limited number of $3 \mathrm{D}$ printed models. Students were asked to respond to questionnaires intended to assess the contribution of $3 \mathrm{D}$ printing in better understanding of product design of mechanical parts. This paper presents the assessment done.

\section{STUDENT EXCERCISES}

The students in MSK220, who were in their $4^{\text {th }}$ semester bachelor program in Mechanical Engineering, were given mandatory exercises to make 3D digital models of available 3D printed models (Fig. 1). They have also been given demonstrations and tutorials in setting printing parameters of the Ultimaker S5 3D printing machine using its control software called Cura. Part of the exercises was in group work to model a safety hook and a door lock, i.e. the models shown in Fig. 1 (c) and (d).
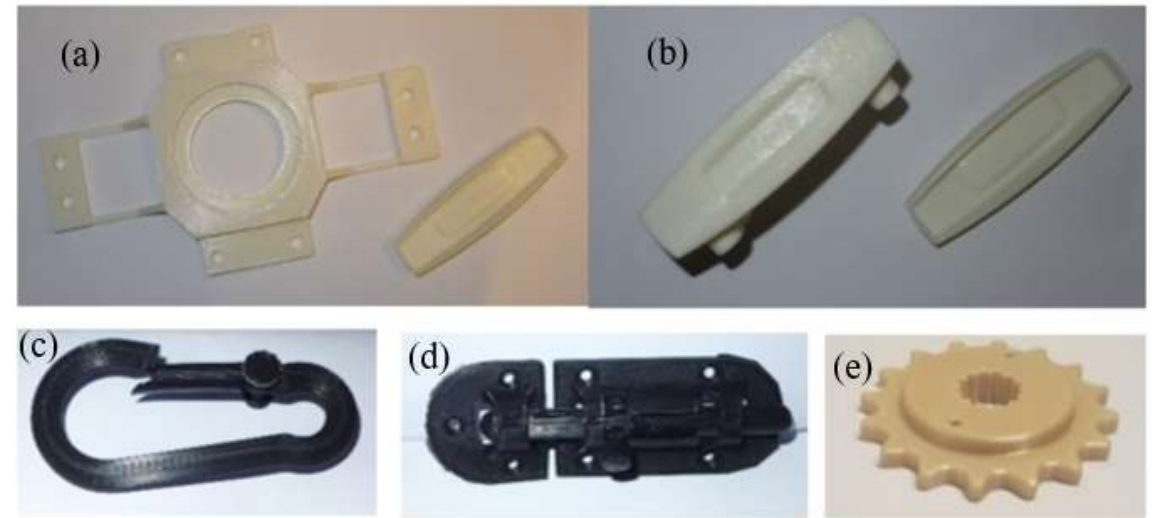

Fig. 1. 3D printed models for 3D modelling group exercises

Upon completing the exercises, the students were requested to respond an online questionnaire consisting of 12 questions. The list of the questions in Norwegian is given in Appendix A.

\section{DISCUSSION OF RESULTS}

\subsection{D modeling and 3D printing results}

The course in product development and 3D modelling was introduced at UiS in 2013 and the 3D modelling tasks were extended with more student exercises in computer-aided design (CAD) already in 2014. The mechanical engineering students at bachelor level at UiS have during the years been recognized as highly motivated in their work with the CAD exercises. 
The safety lock and the door lock assemblies in Fig. 1 exist of five and four separate parts respectively. The exercise given for the group work was about to realize the specific functional demands of the assemblies modelling a digital 3D model using CAD. Most of the students had limited experience with the $3 \mathrm{D}$ printing process in advance of the course. The production of the $3 \mathrm{D}$ printed parts from the student's digital 3D models (Fig. 2) was assisted with UiS laboratory engineer staff. The class discussed with interest both the faulty and the more successful results of their 3D printed parts.

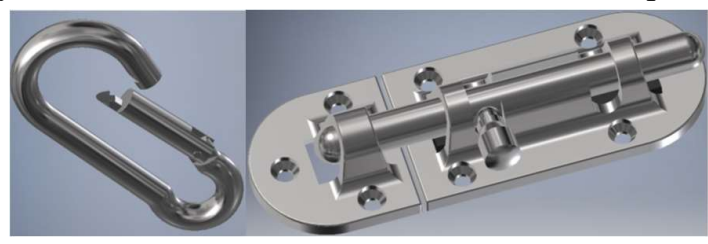

Fig. 2. 3D model results of in CAD software

\subsection{Survey results}

In this section, the results of some of the questions in the survey are discussed. As stated, the exercises were intended to evaluate two issues: (2) Do use of physical models contribute in better understanding of 3D modelling? and (2) Will students get better understanding of product design education if they can transform their design idea in 3D model to a 3D printed physical object?

The survey was conducted with some assumptions and some in advance hypotheses. Among others, it was assumed that the students have no or minor knowledge about 3D printing. This assumption is to assess if the project has contributed in the learning process. The response given in Fig. 3 shows that most of the respondents (95\%) had no or minor knowledge about 3D printing prior to this course.

To begin with, the project team had the hypothesis that use of 3D printing technology contributes to better comprehension of 3D models in CAD tools and mechanical product design process. Accordingly, we wanted to assess if this can be confirmed by the students. Figure 4 shows the response on the extent students agree with this hypothesis. The result shows that only one student disagree with the statement, while 11 of them fully agree and 4 students mostly agree with the statement.

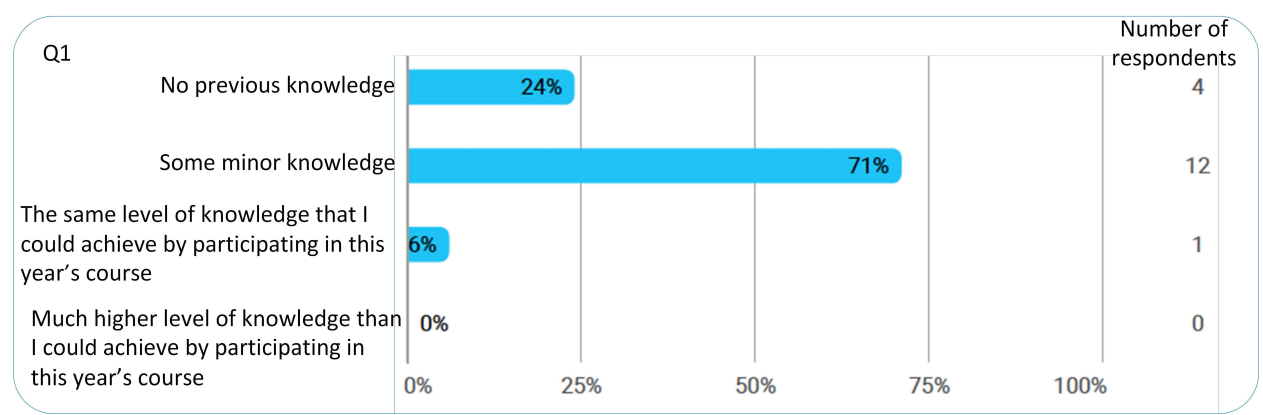

Fig. 3. Student response to Q1: "How would you describe your knowledge of 3D printing technology before the start of the course in MSK220 (January 2019)?"

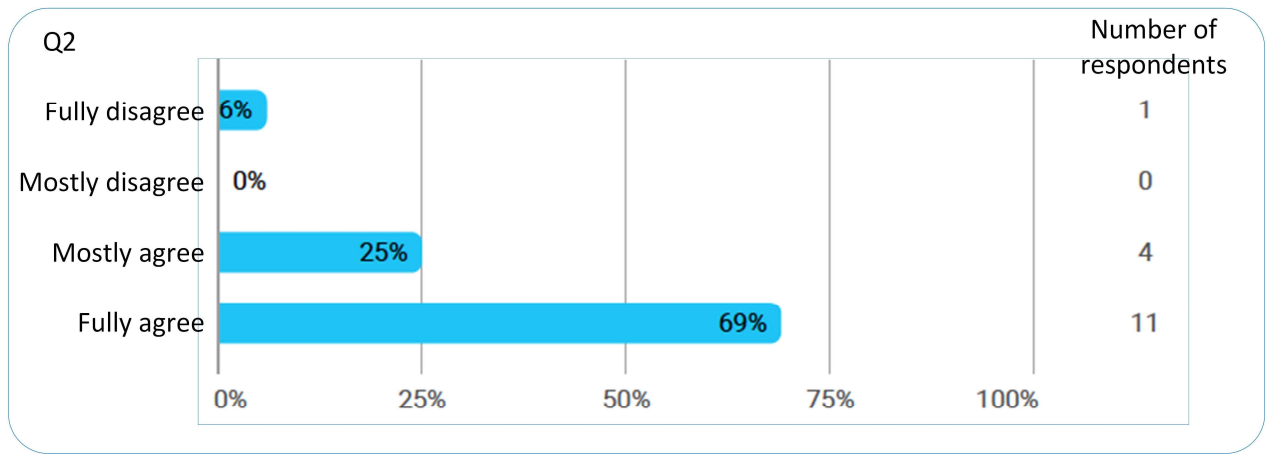

Fig. 4. Student response to Q2: “To what extent do you agree with the following statement: Use of $3 D$ printing technology can contribute to a better understanding of $3 D$ models and mechanical product design? 
The project evaluation was also intended to assess if having 3D printed physical samples in hand, instead of $2 \mathrm{D}$ sketches or dimensional specifications, could better support the modelling task in CAD tool. As depicted in Fig. 5, 20\% of respondents fully agree that the physical samples supported the modelling process while $53 \%$ of them mostly agree. On the other hand, over a quarter of the respondents either fully or mostly disagree with the statement.

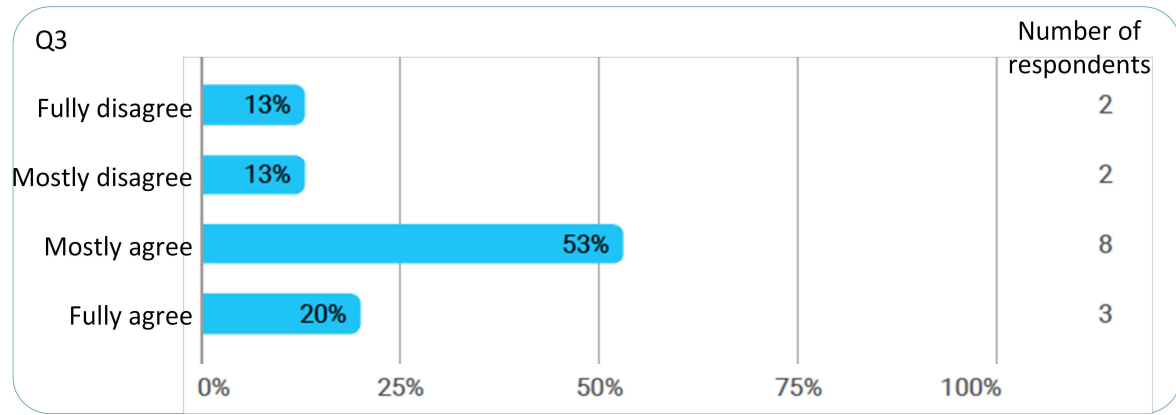

Fig. 5. Student response to Q3: "Do you think that 3D printing technology helped you to support the work process in the modelling task using computer-aided design (CAD) tool?"

As stated earlier, the student groups have 3D printed two of the CAD models they developed as part of the group exercise. This is partly to let them realize the physical model, touch and evaluate it. By so doing, it is also intended to evaluate if the students feel that they better understand exercise by visualizing their idea in three-dimensional space contrary to what they understood in the virtual space. To assess this case, the question "To what extent do you believe that it is useful to be able to realize 3D model using 3D printing?" was forwarded to the students with a scale of 1 to 7 , where 1 is for not useful and 7 is for highly useful. The diagram given in Fig. 6 displays responses of 14 students where all of the respondents expressed its usefulness.

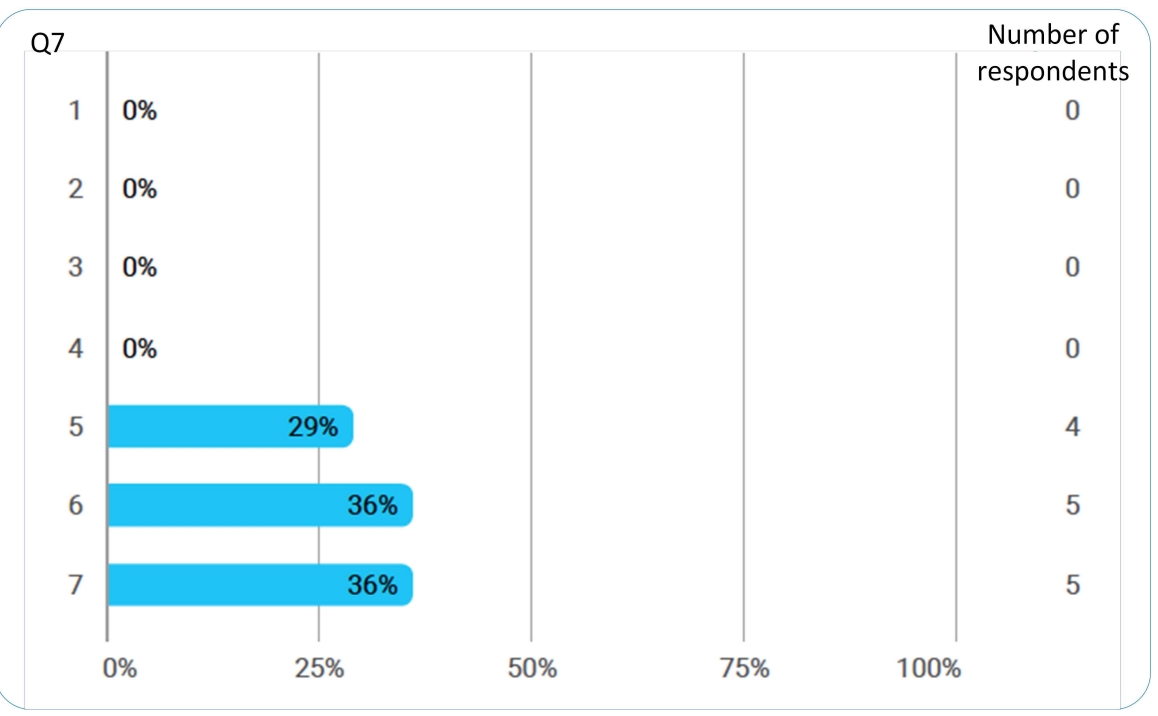

Fig. 6. Student response to Q7: "To what extent do you believe that it is useful to be able to realize $3 D$ model using $3 D$ printing?

\section{CONCLUSION}

This article presented partial results of a project conducted to study the role that 3D printing technology can play in the education sector. The study was conducted by letting students get access to 3D printed parts in their 3D modeling tasks and giving them opportunities to transform their product ideas to a physical object through 3D printing. By so doing, the aim is to evaluate if use of the technology in education has pedagogical value in design comprehension. Part of the assessment was done based on an online survey. According to the assessment results, more than $80 \%$ of the students who participated in the assessment responded that use of 3D fabricated parts in product design tasks have contributed to better understanding of the task and supported its execution. 


\section{REFERENCES}

[1]. Bak, D. (2003) Rapid prototyping or rapid production? 3D printing processes move industry towards the latter, Assembly automation, vol. 23, No. 4, pp. $340-345$.

[2]. Lemu, H.G. (2016), Beyond rapid prototyping: Study of prospects and challenges of 3D printing in functional part fabrication, In: Proceedings of International Workshop of Advanced Manufacturing and Automation (IWAMA 2016), Changshu, China, pp. 138-143.

[3]. Ulas, D. (2019), Digital transformation process and SMEs, Procedia Computer Science, vol. 158, pp. 662671.

[4]. Woodson, T.S. (2015), 3D Printing for Sustainable Industrial Transformation, Development, vol. 58, pp. 571-576.

[5]. Pousttchi, K., Gleiss, A., Buzzi B. and Kohlhagen, M. (2009), Technology impact types for digital transformation, IEEE $21^{\text {st }}$ Conference on Business Informatics (CBI), Moscow, Russia, pp. 487-494.

[6]. Pikkarainen, A., Piili, H and Salminen, A. (2021), Introducing novel learning outcomes and process selection model for additive manufacture for education in engineering, European Journal of education studies, vol. 8, No. 1, pp. $64-87$.

[7]. Chong, S., Pan, G.-T., Chin, J., Show, P.L., Yang, T.C.K. and Huang, C.-M. (2018), Integration of 3D printing and industry 4.0 into engineering teaching. Sustainability, vol. 10, No. (11), 3960.

[8]. Schelly, C., Anzalone, G., Wijnen, B., Pearce, J.M. (2015), Open-source 3-d printing technologies for education: Bringing additive manufacturing to the classroom. Journal of Visual Languages \& Computing vo. 28, pp. 226-237.

[9]. Kostakis, V., Niaros, V. and Giotitsas, C. (2015), Open source 3D printing as a means of learning: An educational experiment in two high schools in Greece, Telematics and Informatics, vol. 32, Issue 1, pp. 118128 ,

[10]. Pantazis, A. and Priavolou, C. (2017), 3D printing as a means of learning and communication: The 3Ducation project revisited, Telematics and Informatics, vol. 34, Issue 8, pp. 1465-1476.

[11]. Ford S. and Minshall, T. (2019), Where and how 3D printing is used in teaching and education, Additive manufacturing, vol. 25, pp. $131-150$.

[12]. Pikkarainen, A. and Piili, H. (2020), Implementing 3D printing education through technical pedagogy and curriculum development. International Journal of Engineering Pedagogy 10(6), pp. 95-119.

\begin{tabular}{|c|c|c|}
\hline \multicolumn{3}{|c|}{ Appendix A: } \\
\hline Nr. & Spørsmål & Respondenter \\
\hline 1 & $\begin{array}{l}\text { Hvordan vil du beskrive dine kunnskaper om 3D printing teknologi før kursstart i } \\
\text { MSK220 (Januar 2019)? }\end{array}$ & 17 \\
\hline 2 & $\begin{array}{l}\text { I hvilken grad er du enig eller uenig i følgende uttalelse: Bruk av 3D printing teknologi } \\
\text { kan bidra til en bedre forståelse av 3D modeller og mekanisk produkt design? }\end{array}$ & 16 \\
\hline 3 & $\begin{array}{l}\text { I hvilken grad er du enig eller uenig i følgende uttalelse: Bruk av 3D printede modeller } \\
\text { støttet meg i arbeidet med DAK oppgavene. }\end{array}$ & 15 \\
\hline 4 & Hvilken del modellerte din gruppe i gruppearbeidet i DAK? & 15 \\
\hline 5 & $\begin{array}{l}\text { Deltok du eller din gruppe under demonstrasjonen og opplæringen i programmet Cura på } \\
\text { PC-lab D-258? }\end{array}$ & 15 \\
\hline 6 & $\begin{array}{l}\text { I hvilken grad ser du noen nytte i å ha deltatt under demonstrasjonen og opplæringen i } \\
\text { programmet Cura? }\end{array}$ & 15 \\
\hline 7 & I hvilken grad mener du at det er nyttig å kunne realisere 3D modeller ved 3D print? & 14 \\
\hline 8 & $\begin{array}{l}\text { Kan du evt. beskrive hvilken nytte du som student kan ha av at vi kan benytte 3D printing } \\
\text { i DAK? }\end{array}$ & \\
\hline 9 & Fikk gruppen se delen etter at den var ferdig produsert? & 13 \\
\hline 10 & Var det samsvar mellom ferdig del og den digitale 3D modellen i Autodesk Inventor? & 12 \\
\hline 11 & $\begin{array}{l}\text { Kan du nærmere beskrive samsvar eller evt. avvik mellom ferdig del og den digitale 3D } \\
\text { modellen gruppen hadde modellert i Autodesk Inventor? }\end{array}$ & \\
\hline 12 & Har du tidligere hatt anledning til å 3D printe DAK modeller som du har laget? & 12 \\
\hline
\end{tabular}

